\title{
Assortative Matching of Tourists and Destinations: Agents or Algorithms?
}

\author{
Ralf Buckley ${ }^{1, *(\mathbb{D})}$ and Mary-Ann Cooper ${ }^{2}$ \\ 1 International Centre for Ecotourism Research, Griffith University, Gold Coast 4222, Australia \\ 2 Instituto Profesional de la Fundacion Duoc UC de la Pontificia Universidad Católica, 2336 Viña del Mar, Chile; \\ minicooper83@gmail.com \\ * Correspondence: r.buckley@griffith.edu.au
}

check for

updates

Citation: Buckley, R.; Cooper, M.-A. Assortative Matching of Tourists and Destinations: Agents or Algorithms? Sustainability 2021, 13, 1987.

https://doi.org/10.3390/su13041987

Academic Editor: Alastair

M. Morrison

Received: 7 January 2021

Accepted: 7 February 2021

Published: 12 February 2021

Publisher's Note: MDPI stays neutral with regard to jurisdictional claims in published maps and institutional affiliations.

Copyright: (c) 2021 by the authors. Licensee MDPI, Basel, Switzerland. This article is an open access article distributed under the terms and conditions of the Creative Commons Attribution (CC BY) license (https:// creativecommons.org/licenses/by/ $4.0 /)$.

\begin{abstract}
We propose that assortative matching, a well-established paradigm in other industry sectors and academic disciplines, can underpin the concept of destination matching. This provides a new foundation to integrate research concepts and terminology in destination marketing and destination choice. We argue that the commercial tourism industry already applies destination matching approaches, with three historical phases. Initially, matching of tourists and destinations relied on the tacit expertise of specialist agents. This still applies in specialist subsectors. For generalist travel and accommodation, human agents were partially replaced by online travel agents, OTAs, which are customised algorithms operating only in the travel sector. These still exist, but their share price trends suggest decreasing significance. Currently, automated assortative algorithms use multiple sources of digital data to push appealing offers to potential purchasers, across all retail sectors. Digital marketing strategies for tourism products, enterprises, and destinations are now just one category of generalised product-purchaser matching, using entirely automated algorithms. Researchers do not have access to proprietary algorithms, but we can identify which components they incorporate by analysing their underlying patents. We propose that theories of destination marketing and choice need to reflect these recent and rapid real-world changes via deliberate analysis of destination matching.
\end{abstract}

Keywords: marketing; choice; brand; image; congruence; assortative; fashion

\section{Introduction}

Every journey matches people with places. Every day, except during global shutdowns, millions of tourists are matched with destinations. In tourism research, this has been analysed via two parallel and complementary fields, destination marketing and destination choice. Of course, these fields overlap. Here, we propose that the overlap itself, the process of matching between destination marketing and tourist destination choice, deserves greater attention. We suggest that it could be analysed as assortative matching. This approach is used widely in other sectors and disciplines, but not currently in tourism research. In tourism practice, destination matching has relied historically on tacit knowledge held by expert travel agents. Currently, the fastest growing mechanism is through cross-links between search engines and social media, delivering customised and targeted purchase opportunities. We argue that tourism research frameworks should include these new practices.

Our approach here is conceptual. As in most research coupled to specific industry sectors, it is commonplace for practical changes in the industry to occur in advance of academic analysis. Few tourists or tourism enterprises read academic articles in tourism journals, and few journal articles make the crossover to mass or social media, or tourism industry communications. As researchers, it is not enough for us to analyse, in ever greater detail, how tourism operates currently. It is equally important for us to analyse trends, and track how tourism is changing. The aim of our contribution here is to suggest, for the 
consideration of other tourism researchers, that a very major change in practical tourism destination marketing and choice is occurring under our noses, but that we have not yet started to examine it. That change is the switch to generalised digital marketing, where tourism has no special dedicated marketing system, as it did in the past. It is just one category of marketable products, amongst many others using the same communications channels and assortative matching algorithms.

To make this argument, we use two sets of published materials; but this is not a review of past literature, nor a meta-analysis of content. We use those materials simply to show what kinds of topics they address: a second-tier, "meta-meta"-analysis. The first set is a simple classification of recent academic publications in destination marketing and choice. We use this solely to show the proliferation of conceptual terminology, at ever finer levels of division. The driving force for this is the tourism journal editorial and review system. Articles are only accepted in high-tier tourism journals, if authors can argue that they make new theoretical contributions. Therefore, authors must continually invent new terminology, in order to make such a case. We do not criticise the individual studies. Our argument is that each adds a diminishing marginal advance in knowledge, a focus on smaller and smaller aspects of historical systems; but that meanwhile, those systems are being replaced by alternative approaches, that are not yet studied at all in a tourism context.

The second set shows what they are being replaced by. It is a sample of patents held by large-scale search and social media corporations, that most of us interact with daily. These patents underlie the algorithms by which they identify what each of us might buy, and present us with customised offers from sellers and suppliers. The algorithms are famously confidential, so, as researchers, we cannot analyse them directly. It seems likely that they are based on neural networks, so that even the corporations that own them can only find out what they do by carrying out experiments, such as Google ${ }^{\circledR}$ Inc's widely reported current experiment on news access by Australian citizens. We can, however, determine their capabilities, by analysing the patents held by their parent corporations. These patents, which are publicly available, set out mechanisms in detail. Here, however, our focus is on capabilities rather than mechanisms: again, a "meta-meta" second-tier approach. What we want to show is that those patents contain the capabilities to supplant the industry practices that form the subject of previous academic research in this field. Moreover, if they do, then our research needs new directions.

\section{Assortative Matching}

Assortative matching occurs whenever two non-substitutable sets of actors or agents each want to choose partners from the other set, subject to constraints and preferences [1-3]. Well-known examples include choice of marriage partners [1,4,5], academic co-authors [6], or residential addresses [7]; allocation of sportspersons between teams [8,9], employees between employers [10,11], or students between universities [12-14]; and reciprocal choice of banks and borrowers [5,15], insurers and insured [15], enterprises and auditors [16], or patients and healthcare providers [17].

\section{Complexities}

Complexities are added where: sets have unequal sizes, with some members unassigned; matching is one-to-many or many-to-one; different members assign different rankings to members of the other set, or are uncertain what rankings to assign; or matches can be rejected, undone, or repeated. Rankings may be based on parameters that are invisible, unquantified, uncertain, or weighted and aggregated differentially by different members [18]. Information and transactions may be subject to costs, uncertainties, deceptions, unavailability, or overload [19-22]. Matching may be constrained by: distance in time or space; legal, cultural, or political barriers; or unequal size or power [7]. All these complexities can apply for assortative matching of tourists and destinations [23-25]. 


\section{Current Frameworks}

Current frameworks for research in destination marketing and destination choice are also complex (Table 1). There are three large-scale frameworks: construction, projection, and perception of destination image; induced, organic, and autonomous information sources; and affective, cognitive, and conative psychological domains. Increasingly finegrained terms have been proposed (Table 1) and criticised [26]. The closest approaches to the destination matching framework proposed here are concepts such as fashionability [24] and congruency [27-32]. None of these used assortative matching frameworks.

Table 1. Destination Marketing and Choice, Frameworks, and Terminology.

\begin{tabular}{ll}
\hline Term or Aspect & References \\
\hline Authenticity & {$[33-38]$} \\
\hline Brand, brand equity, brand engagement, brand complexity & {$[25,33,39-42]$} \\
\hline Choice and bias & {$[43-46]$} \\
\hline Competitiveness & {$[47-50]$} \\
\hline Content & {$[51]$} \\
\hline Communication: construction, projection, perception & {$[52-59]$} \\
\hline Emotions & {$[44,60,61]$} \\
\hline Extension & {$[62]$} \\
\hline Fascination & {$[63]$} \\
\hline Fashionability & {$[24]$} \\
\hline Fragmentation & {$[64]$} \\
\hline Information: induced, organic, autonomous & {$[65-69]$} \\
\hline Loyalty & {$[40,53,70]$} \\
\hline Memorability & {$[46]$} \\
\hline Personality & {$[27,29,31,53]$} \\
\hline Positioning & {$[58,71]$} \\
\hline Psychological domains: affective, cognitive, conative & {$[60,61,72-76]$} \\
\hline Self-concept and self-congruence & {$[28,30,32,40,77-80]$} \\
\hline Compare cultures & {$[81]$} \\
\hline Tourists cf residents & {$[82,83]$} \\
\hline Compare stakeholders & {$[84]$} \\
\hline Damage, repair & {$[85,86]$} \\
\hline Scale & {$[87,88]$} \\
\hline Distance, logistics & {$[23,89,90]$} \\
\hline Change over time & {$[91]$} \\
\hline &
\end{tabular}

\section{Specialist Travel Agents Using Tacit Expertise}

Historically, destination matching has been performed principally by travel agents, who possess knowledge of both destinations and clients. Many tourists have activity preferences, or other criteria restricting destination choice [4,92-94]. This shrinks the sets sufficiently to be matched by specialist travel agents or social-media groups, as in wildlife or adventure tourism [92-95]. In African wildlife tourism, for example, the assortative parameters are: location, luxury, price, wildlife diversity, quality of wildlife viewing, and for some, contributions to conservation and local communities. Priorities are: viewing first, luxury second, and conservation third [95]. Viewing quality depends on: location and available wildlife; lodge history and wildlife habituation; and legal constraints, e.g., 
on open vehicles. Agents aggregate this information as tacit expertise, in order to match their clients to specific destination lodges [95]. This tacit expertise is not codified to algorithmic form.

\section{Specialist Travel and Tourism Algorithms}

In subsectors with high substitutability, such as flight and hotel bookings, global companies adopted assortative matching algorithms to underpin their marketing engines [96-99]. Research has attempted to adapt and codify travel agent practices to generate specialist algorithms [100-103], and to predict whether or not these so-called online travel agents, OTAs, will supersede human expertise [104,105]. In practice, however, we suggest that these first-generation specialist systems are already being superseded. For many of these first-generation algorithmic matchers, share prices are now declining or stabilised. Rather than trying to add OTAs to marketing strategies [106,107], tourism destinations and enterprises now aim to optimise much more generalised digital marketing strategies.

\section{Generalist Algorithms including Tourism}

In the second generation, as large search and social media corporations track individual preferences and circumstances with ever finer detail and timeliness, tourism destinations have become simply one of many products pushed to potential purchasers. Matches are identified through location, personal networks, search and purchase histories, written and oral communications and instructions, and even where one looks on one's computer screen (Table 2). Researchers cannot access proprietary algorithms, but patents show how these methods operate, in considerable detail (Table 2).

Table 2. Relevant Patents Held by Booking, Search, and Social Media Corporations.

\begin{tabular}{llll}
\hline Assignee & Abbreviated Title & Date & Ref \\
\hline Amadeus S.A.S. & Maximum availability inventory & $11 / 20$ & {$[108]$} \\
\hline Amadeus S.A.S. & Product delivery system and method & $08 / 20$ & {$[109]$} \\
\hline Amadeus S.A.S. & Neural network . . application navigation & $09 / 19$ & {$[110]$} \\
\hline Expedia, Inc. & Persona for opaque travel item selection & $10 / 20$ & {$[111]$} \\
\hline Expedia, Inc. & Disambiguating search queries & $07 / 19$ & {$[112]$} \\
\hline Expedia, Inc. & $\ldots$ automated content generation & $07 / 18$ & {$[113]$} \\
\hline Facebook, Inc. & User info ... from third-party applications & $05 / 14$ & {$[114]$} \\
\hline Facebook, Inc. & Determining user personality ... & $08 / 17$ & {$[115]$} \\
\hline Facebook, Inc. & $\ldots$ eye tracking data ... & $10 / 17$ & {$[116]$} \\
\hline Facebook, Inc. & Real-time tracking of offline transactions & $12 / 20$ & {$[117]$} \\
\hline Facebook, Inc. & Modifying capture of video data ... & $12 / 20$ & {$[118]$} \\
\hline Facebook, Inc. & $\ldots$ generating digital channel content & $12 / 20$ & {$[119]$} \\
\hline Facebook, Inc. & Navigating through content items & $12 / 20$ & {$[120]$} \\
\hline Facebook, Inc. & $\ldots$ system for product clustering & $12 / 20$ & {$[121]$} \\
\hline Facebook, Inc. & Face detection for video calls & $12 / 20$ & {$[122]$} \\
\hline Facebook, Inc. & Haptic communication system ... & $12 / 20$ & {$[123]$} \\
\hline Facebook, Inc. & Placing locations in a virtual world & $12 / 20$ & {$[124]$} \\
\hline Facebook, Inc. & Ranking feed based on likelihood of user ... & $12 / 20$ & {$[125]$} \\
\hline Facebook, Inc. & $\ldots$ tailored advertisements in conversation & $12 / 20$ & {$[126]$} \\
\hline Facebook, Inc. & Predicting ... location of online user & $12 / 20$ & {$[127]$} \\
\hline Facebook, Inc. & Wavefront sensing [reflected infrared light] & $12 / 20$ & {$[128]$} \\
\hline Facebook, Inc. & Distribution ... URL's to external websites & $12 / 20$ & {$[129]$} \\
\hline & & & \\
\hline
\end{tabular}


Table 2. Cont.

\begin{tabular}{llll}
\hline Assignee & Abbreviated Title & Date & Ref \\
\hline Facebook, Inc. & Matching and ranking content items & $12 / 20$ & {$[130]$} \\
\hline Facebook, Inc. & $\ldots$ securing data to a . . distributed ledger & $12 / 20$ & {$[131]$} \\
\hline Facebook, Inc. & Computing a ranked feature list ... & $12 / 20$ & {$[132]$} \\
\hline Facebook, Inc. & $\ldots$ analysing insertion points in ... video & $12 / 20$ & {$[133]$} \\
\hline Facebook, Inc. & Capturing a cluster ... targeted ... exposure & $12 / 20$ & {$[134]$} \\
\hline Facebook, Inc. & $\ldots$ data to predict affinity ... content item & $11 / 20$ & {$[135]$} \\
\hline Facebook, Inc. & $\ldots$ performance of content item campaigns & $11 / 20$ & {$[136]$} \\
\hline Facebook, Inc. & Identity prediction for unknown users ... & $11 / 20$ & {$[137]$} \\
\hline Google LLC & Recorded ... hotword trigger suppression & $12 / 20$ & {$[138]$} \\
\hline
\end{tabular}

While one might think that those are intrusive, some countries have now adopted facial recognition technology nationally [139], and suggestions are already being made, only slightly tongue-in-cheek, as to how marketers will shortly sell globalised individual personal data [140].

The patents listed in Table 2 were identified and cross-checked using Google ${ }^{\circledR}$ patent searches, national patent directories (principally USA), litigation reports, corporate annual reports, compulsory stock exchange filings, and professional biographical reports of initial patent owners. Patents listed are only a very small sample of the total held. Most of the patents listed above for Facebook ${ }^{\circledR}$ Inc. were granted in the first half of December 2020, but some were applied for 1-3 years earlier. This may reflect the politics of the 2016-2020 US Administration, which included disputes with technological and social media corporations.

Digital marketing strategies, in tourism as in other retail sectors, now aim to target relevant individuals, identify likely purchases, and present them directly with product offers. Destination marketing organisations use similar approaches, targeting potential visitors through advertising on all forms of digital communications. Under these approaches, offers for tourism products and destinations are treated simply as one form of targetable communication, and identification of potential tourists is simply one form of individualised market targeting. The algorithms used to carry out targeted digital advertising rely on assortative matching as their core process.

\section{Conclusions}

Destination matching does not supersede, contradict, or compete with frameworks for destination marketing and choice. It focusses on the links between them. In addition, it reflects changes in the tourism industry. Assortative matching algorithms are already used to market destinations to tourists via social media. Published research on tourism destination marketing and choice does not currently include assortative matching, and published research on assortative matching does not include tourism. However, now that these assortative matching processes are used increasingly in real-life tourism marketing, we argue that they should also be addressed in tourism research. We therefore propose that, in addition to marketing by destinations and destination choice by tourists, we should analyse the practical processes of assortative matching between tourists and destinations.

The use of generalised digital marketing, in tourism as in other sectors (including universities), has been expanding over the past few years. Most tourism destinations and enterprises routinely include a range of paid and unpaid search optimisation strategies, social media campaigns, and other digital matching approaches in their marketing portfolios. Meanwhile, in 2020 and perhaps also 2021, the tourism industry worldwide has experienced a major hiatus as a result of the COVID-19 pandemic, with international travel almost abolished, and even domestic travel severely curtailed. This has provided an opportunity to restructure products, itineraries, and marketing, including destination 
marketing. National tourism marketing agencies and portfolios recognise this well. As of 28 January 2021, for example, Tourism New Zealand has launched a new campaign that does not seek to sell directly, but rather to influence the selection of specific destinations within New Zealand that are featured by private social media influencers [141].

The degree to which this strategy succeeds will provide a partial practical test of the arguments we make here, but at a very broad scale. From a research perspective, we can focus on destination matching mechanisms, testing how much tourists rely on the use of different digital sources to identify future destinations. The first tenet of marketing, perhaps, is to make people with money want what one has to sell. The combination of search and social media algorithms can achieve that, par excellence. Should we not study how that works, for tourism specifically?

Author Contributions: R.B.: conceptualisation, data, draft, final text. M.-A.C., conceptualisation, data, draft. All authors have read and agreed to the published version of the manuscript.

Funding: This research received no external funding.

Institutional Review Board Statement: Not applicable.

Informed Consent Statement: Not applicable.

Data Availability Statement: All data in article.

Conflicts of Interest: The authors declare no conflict of interest.

\section{References}

1. Becker, G.S. A Theory of Marriage: Part I. J. Politi. Econ. 1973, 81, 813-846. [CrossRef]

2. Shimer, R.; Smith, L. Assortative Matching and Search. Econometrica 2000, 68, 343-369. [CrossRef]

3. Yang, C.-L.; Yue, C.-S.J. Cooperation in an Assortative Matching Prisoners Dilemma Experiment with Pro-Social Dummies. Sci. Rep. 2019, 9, 13609. [CrossRef] [PubMed]

4. Adams, J.; Schaefer, D.R.; Vest-Ettekal, A. Crafting Mosaics: Person-Centered Religious Influence and Selection in Adolescent Friendships. J. Sci. Study Relig. 2020, 59, 39-61. [CrossRef] [PubMed]

5. Fu, H.; Yang, J.; An, Y. Made for each other: Perfect matching in venture capital markets. J. Bank. Financ. 2019, 100, 346-358. [CrossRef]

6. Besancenot, D.; Huynh, K.; Serranito, F. Co-authorship and research productivity in economics: Assessing the assortative matching hypothesis. Econ. Model. 2017, 66, 61-80. [CrossRef]

7. Modai-Snir, T.; Plaut, P. The analysis of residential sorting trends: Measuring disparities in socio-spatial mobility. Urban. Stud. 2019, 56, 288-300. [CrossRef] [PubMed]

8. Drut, B.; Duhautois, R. Assortative matching using soccer data: Evidence of mobility bias. J. Sports Econ. 2017, 18, 431-447. [CrossRef]

9. Yang, Y.; Shi, M.; Goldfarb, A. Estimating the Value of Brand Alliances in Professional Team Sports. Mark. Sci. 2009, 28 , 1095-1111. [CrossRef]

10. Haylock, M.; Kampkötter, P. The role of preferences, attitudes, and personality traits in labor market matching. Econ. Lett. 2019, 185, 108718. [CrossRef]

11. Lopes de Melo, R. Firm wage differentials and labor market sorting: Reconciling theory and evidence. J. Polit. Econ. 2018, 126, 313-346. [CrossRef]

12. Dillon, E.W.; Smith, J.A. Determinants of the Match between Student Ability and College Quality. J. Labor Econ. 2017, 35, 45-66. [CrossRef]

13. Dillon, E.W.; Smith, J.A. The Consequences of Academic Match between Students and Colleges. J. Hum. Resour. 2020, 55, 767-808. [CrossRef]

14. $\mathrm{Hu}, \mathrm{X}$. Sorting big data by revealed preference with application to college ranking. J. Big Data 2020, 7, 1-26. [CrossRef]

15. Akkus, O.; Cookson, J.A.; Hortaçsu, A. Assortative Matching and Reputation in the Market for First Issues. Manag. Sci. 2020. [CrossRef]

16. Bills, J.L.; Jensen, L. Auditor-client pairing: A positive assortative matching market. J. Account. Res. 2010, 13, 1-38.

17. Schmidt, B. Systems and methods for using aggregate community health statistics in connection with disease prevention programs. US Patent Application 106909, 2018.

18. Diamond, W.; Agarwal, N. Latent indices in assortative matching models. Quant. Econ. 2017, 8, 685-728. [CrossRef]

19. Bapna, R.; Dellarocas, C.; Rice, S. Vertically Differentiated Simultaneous Vickrey Auctions: Theory and Experimental Evidence. Manag. Sci. 2010, 56, 1074-1092. [CrossRef]

20. Bjerre-Nielsen, A. Assortative matching with network spillovers. J. Econ. Theory 2020, 187, 105028. [CrossRef] 
21. Hoppe, H.C.; Moldovanu, B.; Sela, A. The Theory of Assortative Matching Based on Costly Signals. Rev. Econ. Stud. 2009, 76, 253-281. [CrossRef]

22. Pivnick, L.K.; Gordon, R.A.; Crosnoe, R. Crowd Sourcing: Do Peer Crowd Prototypes Match Reality? Soc. Psychol. Q. 2020, 83, 272-293. [CrossRef]

23. Cao, J.; Zhang, J.; Wang, C.; Hu, H.; Yu, P. How Far Is the Ideal Destination? Distance Desire, Ways to Explore the Antinomy of Distance Effects in Tourist Destination Choice. J. Travel Res. 2019, 59, 614-630. [CrossRef]

24. Lewis, C.; Kerr, G.; Burgess, L. Positioning a destination as fashionable: The destination fashion conditioning framework. Tour. Manag. 2019, 72, 209-219. [CrossRef]

25. Guervos, R.A.C.; Jamilena, D.M.F.; Peña, A.I.P.; Olmo, J.C. Influence of Tourist Geographical Context on Customer-Based Destination Brand Equity: An Empirical Analysis. J. Travel Res. 2018, 59, 107-119. [CrossRef]

26. Avis, M.; Forbes, S.; Ferguson, S. the brand personality of rocks: A critical evaluation of a brand personality scale. Market. Theory 2013, 14, 451-475. [CrossRef]

27. Bekk, M.; Spörrle, M.; Kruse, J. The Benefits of Similarity between Tourist and Destination Personality. J. Travel Res. 2016, 55, 1008-1021. [CrossRef]

28. Chon, K.-S. Self-image/destination image congruity. Ann. Tour. Res. 1992, 19, 360-363. [CrossRef]

29. Ekinci, Y.; Hosany, S. Destination Personality: An Application of Brand Personality to Tourism Destinations. J. Travel Res. 2006, 45, 127-139. [CrossRef]

30. Kumar, V. Examining the role of destination personality and self-congruity in predicting tourist behavior. Tour. Manag. Perspect. 2016, 20, 217-227. [CrossRef]

31. Papadimitriou, D.; Apostolopoulou, A.; Kaplanidou, K. Destination Personality, Affective Image, and Behavioral Intentions in Domestic Urban Tourism. J. Travel Res. 2013, 54, 302-315. [CrossRef]

32. Sirgy, M.J.; Su, C. Destination image, self-congruity, and travel behaviour: Toward an integrative model. J. Trav. Res. 2000, 38, 340-352. [CrossRef]

33. Engeset, M.G.; Elvekrok, I. Authentic concepts: Effects on tourist satisfaction. J. Trav. Res. 2015, 54, 456-466. [CrossRef]

34. Fu, X. Existential authenticity and destination loyalty: Evidence from heritage tourists. J. Destin. Mark. Manag. 2019, 12, 84-94. [CrossRef]

35. Park, E.; Choi, B.-K.; Lee, T.J. The role and dimensions of authenticity in heritage tourism. Tour. Manag. 2019, 74, 99-109. [CrossRef]

36. Yi, X.; Lin, V.S.; Jin, W.; Luo, Q. The Authenticity of Heritage Sites, Tourists' Quest for Existential Authenticity, and Destination Loyalty. J. Travel Res. 2016, 56, 1032-1048. [CrossRef]

37. Zhou, Q.; Zhang, J.; Zhang, H.; Ma, J. A structural model of host authenticity. Ann. Tour. Res. 2015, 55, 28-45. [CrossRef]

38. Zhu, Y. Cultural effects of authenticity: Contested heritage practices in China. Int. J. Heritage Stud. 2015, 21, 594-608. [CrossRef]

39. Campelo, A.; Aitken, R.; Thyne, M.; Gnoth, J. Sense of place: The importance for destination branding. J. Trav. Res. 2014, 53, 154-166. [CrossRef]

40. Chen, R.; Zhou, Z.; Zhan, G.; Zhou, N. The impact of destination brand authenticity and destination brand self-congruence on tourist loyalty: The mediating role of destination brand engagement. J. Destin. Mark. Manag. 2020, 15, 100402. [CrossRef]

41. Kavaratzis, M.; Hatch, M.J. The Elusive Destination Brand and the ATLAS Wheel of Place Brand Management. J. Travel Res. 2021, 60, 3-15. [CrossRef]

42. Zenker, S.; Braun, E.; Petersen, S. Branding the destination versus the place: The effects of brand complexity and identification for residents and visitors. Tour. Manag. 2017, 58, 15-27. [CrossRef]

43. Hsu, T.-K.; Tsai, Y.-F.; Wu, H.-H. The preference analysis for tourist choice of destination: A case study of Taiwan. Tour. Manag. 2009, 30, 288-297. [CrossRef]

44. Pestana, M.H.; Parreira, A.; Moutinho, L. Motivations, emotions and satisfaction: The keys to a tourism destination choice. J. Destin. Mark. Manag. 2020, 16, 100332. [CrossRef]

45. Wattanacharoensil, W.; La-Ornual, D. A systematic review of cognitive biases in tourist decisions. Tour. Manag. 2019, 75, 353-369. [CrossRef]

46. Ye, S.; Wei, W.; Wen, J.; Ying, T.; Tan, X. Creating Memorable Experience in Rural Tourism: A Comparison between Domestic and Outbound Tourists. J. Travel Res. 2020. [CrossRef]

47. Armenski, T.; Dwyer, L.; Pavluković, V. Destination Competitiveness: Public and Private Sector Tourism Management in Serbia. J. Travel Res. 2017, 57, 384-398. [CrossRef]

48. Cvelbar, L.K.; Dwyer, L.; Koman, M.; Mihalič, T. Drivers of destination competitiveness in tourism: A global investigation. J. Trav. Res. 2016, 55, 1041-1050. [CrossRef]

49. De Souza, J.; Mendes-Filho, L.; Buhalis, D. Evaluating the effectiveness of tourist advertising to improve the competitiveness of destinations. Tour. Econ. 2019, 26, 1001-1020. [CrossRef]

50. Koc, E. Destination competitiveness, the environment and sustainability challenges and cases. Ann. Tour. Res. 2016, 58, 177-178. [CrossRef]

51. Kock, F.; Josiassen, A.; Assaf, A.G. Advancing destination image: The destination content model. Ann. Tour. Res. 2016, 61, 28-44. [CrossRef]

52. Beerli, A.; Martín, J.D. Factors influencing destination image. Ann. Tour. Res. 2004, 31, 657-681. [CrossRef] 
53. Chen, C.-F.; Phou, S. A closer look at destination: Image, personality, relationship and loyalty. Tour. Manag. 2013, 36, 269-278. [CrossRef]

54. Govers, R.; Go, F.M. Cultural identities constructed, imagined and experienced: A 3-gap tourism destination image model. Tourism 2004, 52, 165-182.

55. Huang, Y.; Qu, H.; Montgomery, D. The Meanings of Destination: A Q Method Approach. J. Travel Res. 2016, 56, 793-807. [CrossRef]

56. Hunter, W.C. The social construction of tourism online destination image: A comparative semiotic analysis of the visual representation of Seoul. Tour. Manag. 2016, 54, 221-229. [CrossRef]

57. Lai, K.; Li, X.R. Tourism destination image conceptual problems and definitional solutions. J. Trav. Res. 2016, 55, 1065-1080. [CrossRef]

58. Pike, S.D.; Ryan, C.A. Destination Positioning Analysis through a Comparison of Cognitive, Affective, and Conative Perceptions. J. Travel Res. 2004, 42, 333-342. [CrossRef]

59. Sun, M.; Ryan, C.; Pan, S. Using Chinese travel blogs to examine perceived destination image: The case of New Zealand. J. Trav. Res. 2015, 54, 543-555. [CrossRef]

60. Hosany, S.; Prayag, G.; Deesilatham, S.; Cauševic, S.; Odeh, K. Measuring tourists' emotional experiences: Further validation of the destination emotion scale. J. Trav. Res. 2014, 54, 482-495. [CrossRef]

61. Prayag, G.; Hosany, S.; Muskat, B.; del Chiappa, G. Understanding the Relationships between Tourists' Emotional Experiences, Perceived Overall Image, Satisfaction, and Intention to Recommend. J. Travel Res. 2017, 56, 41-54. [CrossRef]

62. Kim, H.; Stepchenkova, S.; Yilmaz, S. Destination Extension: A Faster Route to Fame for the Emerging Destination Brands? J. Travel Res. 2019, 58, 440-458. [CrossRef]

63. Wang, Y.-C.; Liu, C.-R.; Huang, W.-S.; Chen, S.-P. Destination Fascination and Destination Loyalty: Subjective Well-Being and Destination Attachment as Mediators. J. Travel Res. 2019, 59, 496-511. [CrossRef]

64. Camprubí, R.; Coromina, L. The role of information sources in image fragmentation. Ann. Tour. Res. 2016, 57, 242-245. [CrossRef]

65. Fakeye, P.C.; Crompton, J.L. Image Differences between Prospective, First-Time, and Repeat Visitors to the Lower Rio Grande Valley. J. Travel Res. 1991, 30, 10-16. [CrossRef]

66. Lian, T.; Yu, C. Impacts of online images of a tourist destination on tourist travel decision. Tour. Geogr. 2019, 21, 635-664. [CrossRef]

67. Llodrà-Riera, I.; Martínez-Ruiz, M.P.; Jiménez-Zarco, A.I.; Izquierdo-Yusta, A. A multidimensional analysis of the information sources construct and its relevance for destination image formation. Tour. Manag. 2015, 48, 319-328. [CrossRef]

68. Michaelidou, N.; Siamagka, N.-T.; Moraes, C.; Micevski, M. Do Marketers Use Visual Representations of Destinations That Tourists Value? Comparing Visitors' Image of a Destination with Marketer-Controlled Images Online. J. Travel Res. 2013, 52, 789-804. [CrossRef]

69. Tseng, C.; Wu, B.; Morrison, A.M.; Zhang, J.; Chen, Y.-C. Travel blogs on China as a destination image formation agent: A qualitative analysis using Leximancer. Tour. Manag. 2015, 46, 347-358. [CrossRef]

70. Stylos, N.; Bellou, V. Investigating Tourists' Revisit Proxies: The Key Role of Destination Loyalty and Its Dimensions. J. Travel Res. 2019, 58, 1123-1145. [CrossRef]

71. Pezenka, I. Paired Comparisons or Sorting? Comparing Web-Based Methods for Collecting Similarity Data for Large Stimulus Sets for Destination Image Positioning. J. Travel Res. 2016, 56, 482-495. [CrossRef]

72. Afshardoost, M.; Eshaghi, M.S. Destination image and tourist behavioural intentions: A meta-analysis. Tour. Manag. 2020, 81, 104154. [CrossRef]

73. Assaker, G.; Hallak, R. Moderating Effects of Tourists' Novelty-Seeking Tendencies on Destination Image, Visitor Satisfaction, and Short- and Long-Term Revisit Intentions. J. Travel Res. 2013, 52, 600-613. [CrossRef]

74. Baloglu, S.; Brinberg, D. Affective Images of Tourism Destinations. J. Travel Res. 1997, 35, 11-15. [CrossRef]

75. Baloglu, S.; McCleary, K.W. A model of destination image formation. Ann. Tour. Res. 1999, 26, 868-897. [CrossRef]

76. Chen, C.F.; Tsai, D. How destination image and evaluative factors affect behavioral intentions? Tour. Manage. 2007, 28, 1115-1122 [CrossRef]

77. Correia, A.; Kozak, M.; Reis, H. Conspicuous consumption of the elite: Social and self-congruity in tourism choices. J. Trav. Res. 2016, 55, 738-750. [CrossRef]

78. Beerli, A.; Meneses, G.D.; Gil, S.M. Self-congruity and destination choice. Ann. Tour. Res. 2007, 34, 571-587. [CrossRef]

79. Li, S.; Wei, M.; Qu, H.; Qiu, S. How does self-image congruity affect tourists' environmentally responsible behavior? J. Sustain. Tour. 2020, 28, 2156-2174. [CrossRef]

80. Luna-Cortés, G.; López-Bonilla, L.M.; López-Bonilla, J.M. The influence of social value and self-congruity on interpersonal connections in virtual social networks by Gen-Y tourists. PLoS ONE 2019, 14, e0217758. [CrossRef]

81. Chen, C.-C.; Lai, Y.-H.; Petrick, J.F.; Lin, Y.-H. Tourism between divided nations: An examination of stereotyping on destination image. Tour. Manag. 2016, 55, 25-36. [CrossRef]

82. Stylidis, D. Exploring resident-tourist interaction and its impact on tourists. J. Travel Res. 2020. [CrossRef]

83. Stylidis, D. Exploring Resident-Tourist Interaction and its Impact on Tourists' Destination Image. Tour. Manage. 2017, 58, 184-195. [CrossRef] 
84. Stylidis, D.; Shani, A.; Belhassen, Y. Testing an integrated destination image model across residents and tourists. Tour. Manag. 2017, 58, 184-195. [CrossRef]

85. Jabreel, M.; Huertas, A.; Moreno, A. Semantic analysis and the evolution towards participative branding: Do locals communicate the same destination brand values as DMOs? PLoS ONE 2018, 13, e0206572. [CrossRef] [PubMed]

86. Avraham, E. Destination image repair during crisis: Attracting tourism during the Arab Spring uprisings. Tour. Manag. 2015, 47, 224-232. [CrossRef]

87. Salvatierra, J.; Walters, G. The impact of human-induced environmental destruction on destination image perception and travel behaviour: The case of Australia's Great Barrier Reef. J. Vacat. Market. 2016, 23, 73-84. [CrossRef]

88. Stepchenkova, S.; Shichkova, E. Country and Destination Image Domains of a Place: Framework for Quantitative Comparison. J. Travel Res. 2016, 56, 776-792. [CrossRef]

89. Nicolau, J.L.; Más, F.J. Stochastic modelling: A three-stage tourist choice process. Ann. Tour. Res. 2005, 32, 49-69. [CrossRef]

90. Nicolau, J.L.; Más, F.J. The influence of distance and prices on the choice of tourist destinations: The moderating role of motivations. Tour. Manag. 2006, 27, 982-996. [CrossRef]

91. Smith, W.W.; Li, X.; Pan, B.; Witte, M.; Doherty, S.T. Tracking destination image across the trip experience with smartphone technology. Tour. Manag. 2015, 48, 113-122. [CrossRef]

92. Buckley, R.C. Surf tourism and sustainable development in Indo-Pacific Islands. I. The industry and the islands. J. Sust. Tour. 2002, 10, 405-424. [CrossRef]

93. Buckley, R.C. Aging Adventure Athletes Assess Achievements and Alter Aspirations to Maintain Self-Esteem. Front. Psychol. 2018, 9, 225. [CrossRef]

94. Buckley, R.; Guitart, D.; Shakeela, A. Contested surf tourism resources in the Maldives. Ann. Tour. Res. 2017, 64, 185-199. [CrossRef]

95. Buckley, R.; Mossaz, A. Decision making by specialist luxury travel agents. Tour. Manag. 2016, 55, 133-138. [CrossRef]

96. Bull, D.S.; Carr, R.N.; Offutt, J.R. Information Aggregation and Synthesisation System. U.S. Patent 78906752, 15 February 2011.

97. Elliot, S.; Papadopoulos, N.; Kim, S.S. An integrative model of place image: Exploring relationships between destination, product, and country images. J. Trav. Res. 2010, 50, 520-534. [CrossRef]

98. Vakil, S.J.; Kaufer, S.; Rosenberg, A. Social Travel Recommendations. U.S. Patent 20130024391, 24 January 2014.

99. Wallace, G.W.; Perks, B.; Hamm, M.E.; Williams, J.M.; Long, W.G.; Zumsteg, D.J.; Tuck-Lee, M.S.; Ha, L.C. Systems and Methods for Generating Travel Packages Including Separately Purchased Travel Items. U.S. Patent 8600805, 2013.

100. Fajar, A.N.; Nurcahyo, A.; Qomariyah, N.N. Online Travel Agent for Tourism System Using Big Data and Cloud. J. Environ. Manag. Tour. 2020, 11, 396-402. [CrossRef]

101. Pencarelli, T. The digital revolution in the travel and tourism industry. Inf. Technol. Tour. 2020, 22, 455-476. [CrossRef]

102. Renjith, S.; Sreekumar, A.; Jathavedan, M. An extensive study on the evolution of context-aware personalized travel recommender systems. Inf. Process. Manag. 2020, 57, 102078. [CrossRef]

103. Schiaffino, S.; Amandi, A. Building an expert travel agent as a software agent. Expert Syst. Appl. 2009, 36, 1291-1299. [CrossRef]

104. Shi, S.; Gong, Y.; Gursoy, D. Antecedents of Trust and Adoption Intention toward Artificially Intelligent Recommendation Systems in Travel Planning: A Heuristic-Systematic Model. J. Travel Res. 2020. [CrossRef]

105. Abrate, G.; Bruno, C.; Erbetta, F.; Fraquelli, G. Which Future for Traditional Travel Agencies? A Dynamic Capabilities Approach. J. Travel Res. 2019, 59, 777-791. [CrossRef]

106. Wong, E.; Rasoolimanesh, S.M.; Sharif, S.P. Using online travel agent platforms to determine factors influencing hotel guest satisfaction. J. Hosp. Tour. Technol. 2020, 11, 425-445. [CrossRef]

107. Ye, F.; Yan, H.; Wu, Y. Optimal online channel strategies for a hotel considering direct booking and cooperation with an online travel agent. Int. Trans. Oper. Res. 2017, 26, 968-998. [CrossRef]

108. Pellerin, F.; Bossert, V.; Mourges, F.; Boudia, M.; Delahaye, T.; Mousli, B.; Cheinet, A.; Lardeux, B. Maximal Availability Inventory. U.S. Patent 10824965, 2020.

109. Becker, M.; Laperrousaz, V.; Pauchet, D. Product Delivery System and Method. U.S. Patent 10740824, 2020.

110. Rollat, G.; Dutto, J.; Kwong, K. Neural Network Systems and Methods for Application Navigation. U.S. Patent 20190279080, 2019.

111. Knight, M.J. Persona for Opaque Travel Item Selection. U.S. Patent 10817922, 2020.

112. Linda, O.; Chan, K.M.; Prakasam, P.K.; Lingamneni, A.; Myrick, S.W.; Simfukwe, S. Disambiguating Search Queries. U.S. Patent 10360276, 2019.

113. Waksberg, R.; Hsu, D.; Bradley, P. Systems and Methods for Automated Content Generation. U.S. Patent 10025770, 2018.

114. Lessin, S.; Lindsay, R.T.; Shaffer, J.A.; Felton, N. Receiving Information About a User from a Third-Party Application Based on Action Types. U.S. Patent 8732802, 2014.

115. Nowak, M.; Eckles, D. Determining User Personality Characteristics from Social Networking System Communications and Characteristics. U.S. Patent 9740752, 2017.

116. Johansen, S.A.; Skovsgaard, H.H.T.; Tall, M.H.; Lopez, J.S. Systems and Methods of Eye Tracking data. U.S. Patent 9798382, 2017.

117. Cohn, Y.; Hollington, S. Real-Time Tracking of Offline Transactions. U.S. Patent 20200394681, 2020.

118. Cheung, V.C. Modifying Capture of Video Data by an Image Capture Device Based on Video Data Previously Captured by the Image Capture Device. U.S. Patent 01868955, 2020. 
119. Underwood, P.J.R.; Teehan, G.D.J.; Kedenburg, G.L.; Holland, J. Systems and Methods for Generating Digital Channel Content. U.S. Patent 10868788, 2020.

120. Richardson, M.A. Navigating Through Content Items on a Computing Device. U.S. Patent 10867320, 2020.

121. Jadhav, R.A.; Khandelwal, S.; Sachdev, G.B.; Gupta, N. Method, Media and System for Product Clustering. U.S. Patent 10867336, 2020.

122. Taine, S.; Aronoff, B.B.; Clark, J. Face Detection for Video Calls. U.S. Patent 10867163, 2020.

123. Israr, I.; Abnousi, F.; Lau, F.W.Y. Haptic Communication System Using Cutaneous Actuators for Simulation of Continuous Human Touch. U.S. Patent 10867526, 2020.

124. Crow, D.E. Placing Locations in a Virtual World. U.S. Patent 10861056, 2020.

125. Xiao, Z.; Xu, J. Ranking Feed Based on a Likelihood of a User Posting Original Broadcast Story in a Session. U.S. Patent 10860589, 2020.

126. Clark, J.D.; Padget, B.K.; Lang, C.J. Messenger Application Plug-in for Providing Tailored Advertisements within a Conversation Thread. U.S. Patent 10861061, 2020.

127. Tseng, E. Predicting a Physical Location of an Online System User from Multiple Candidate Physical Locations Based on a Geographic Location of a Client Device Associated with the User. U.S. Patent 10863316, 2020.

128. Sharma, R.; Ouderkirk, A.J. Waveform Sensing with Ellipsoidal Lensing Structure. U.S. Patent 10852551, 2020.

129. Lin, J.R.; de la Calle, D.O.; Strauss, E.A. Managing Distribution of Content Items Including URL's to External Websites. U.S. Patent 10853431, 2020.

130. Saxena, S.S.; Markov, S.; Wang, F.; Salvana, E.I.T.; Schurman, W.T.; Ahres, Y. Matching and Ranking Content Items. U.S. Patent 10856050, 2020.

131. Leach, F.R.; Corey, M.R.; Taubeneck, E.; Chapsky, D.K. Systems and Methods for Securing Data to an Immutable Distributed Ledger. U.S. Patent 10855475, 2020.

132. Iannaccone, G. Computing a Ranked Feature List for Content Distribution in a First Categorization Stage and Second Ranking stage via Machine Learning. U.S. Patent 10853428, 2020.

133. Bapna, A.; Huang, E.H.C.; Li, S.; Liu, W.; Li, M. Dynamically Providing Digital Content to Client Devices by Analysing Insertion Points within a Digital video. U.S. Patent 10856022, 2020.

134. Liu, W.; Bannikov, A.V. Capturing a Cluster Effect with Targeted Digital-Content Exposures. U.S. Patent 10846564, 2020.

135. Zhang, Z.; Zhang, H.; Tang, J.B.; Kleban, J.T.; Gavlovski, A.S.; Song, H.; Lue, D.B.; Bhalgat, A.S. Generating Data to Predict User Affinity for a Component to be Included in a Content Item Optimized for an Online System User. U.S. Patent 10846751, 2020.

136. Aragonda, P.; Kumar, S.B. Predicting Performance of Content Image Campaigns. U.S. Patent 10839418, 2020.

137. Belous, V. Identity Prediction for Unknown Users of an Online System. U.S. Patent 10839313, 2020.

138. Gruenstein, A.H.; Schalkwyk, J.; Sharifi, M. Recorded Media Hotword Trigger Suppression. U.S. Patent 10867600, 2020.

139. Van Noorden, R. The ethical questions that haunt facial-recognition research. Nat. Cell Biol. 2020, 587, 354-358. [CrossRef] [PubMed]

140. Coen, P. The list. Nat. Cell Biol. 2020. [CrossRef]

141. Picheta, R. New Zealand Tells Tourists to Stop Copying Other People's Travel Photos. Available online: https://edition.cnn.com/ travel/article/new-zealand-tourist-photos-campaign-scli-intl/index.html (accessed on 28 January 2021). 